\title{
Gorontalo
}

Journal of Public Health

Volume 3 - No. 1 - April 2020

P-ISSN: 2614-5057, E-ISSN: 2614-5065

\section{Pengaruh Penambahan Tepung Labu Kuning terhadap Kandungan Karbohidrat dan Protein Cookies}

\section{Effect of Addition Yellow Pumpkin Flour in Cookies Carbohydrate and proteins Content}

\author{
Herman Hatta ${ }^{*}$, Marselia Sandalayuk ${ }^{2}$ \\ ${ }^{1}$ Program Studi Gizi, Fakultas Kesehatan Masyarakat, Univeristas Gorontalo \\ Gorontalo, Indonesia \\ *email: hattaherman.1988@gmail.com \\ ${ }^{2}$ Program Studi Ilmu Kesehatan Masyarakat, Fakultas Kesehatan Masyarakat, \\ Univeristas Gorontalo, Gorontalo, Indonesia
}

\begin{abstract}
Yellow pumpkin is a commodity that is easily damaged so it needs for off harvest handling including preservation and processing. This study was aimed to determine the carbohydrate, protein content of pumpkin flour and get the best formulation in making cookies from pumpkin flour. The research method used was true experimental design using with completely randomized design (CRD) with variations in the addition of pumpkin flour in the treatment of PO (60 gr), P1 (100 gr), P2 (150 gr), P3 (150 gr), P4 (250 gr) with two replications. Based on the results of the cookie test, the highest carbohydrate content in PO treatment was $59.12 \%$ in treatment 1 and $57.61 \%$ in treatment 2 while the lowest in P4 treatment was $51.36 \%$ in replication 1 and 51.83\% in replications 2, analysis of variance showed that carbohydrates in cookies significantly affected with addition of pumpkin flour, based on further analysis Duncan's test results $(p<0.00)$. Protein analysis test results showed that the highest protein content in treatment P4 was $8.44 \%$ replications 1 and $7.46 \%$ in replications 2, while the lowest in treatment $P O$ was $7.17 \%$ replications 1 and $7.44 \%$ in replications 2, analysis the variance showed that the protein in cookies had a very significant effect on the addition of pumpkin flour, based on further analysis Duncan's test results $(p<0.00)$. It was concluded that the addition of pumpkin flour significantly affected in carbohydrate and protein levels in cookies.
\end{abstract}

Keywords: cookies; carbohydrate; yellow pumkin; protein

\begin{abstract}
Abstrak
Labu kuning adalah komoditas yang mudah rusak sehingga perlu adanya penanganan lepas panen termasuk pengawetan dan pengolahan.Penelitian ini bertujuan untuk mengetahui kandungan karbohidrat, protein dari tepung labu kuning serta mendapatkan formulasi terbaik dalam pembuatan cookies dari tepung labu kuning. Metode penelitian yang digunakan adalah true experimental design menggunakan rancangan acak lengkap (RAL) dengan variasi penambahan tepung labu kuning pada perlakuan P0 (60 gr), P1 (100 gr), P2 (150 gr), P3 (200 gr), P4 (250 gr) dengan perlakuan dua kali ulangan. Berdasarkan hasil uji kue cookies menunjukkan kandungan karobohidat tertinggi pada perlakuan PO sebesar $59,12 \%$ pada pengulangan 1 dan $57,61 \%$ pada pengulangan 2 sedangkan terendah pada perlakuan P4 sebesar 51,36\% pada pengulangan 1 dan $51,83 \%$ pada pengulangan 2 , analisa sidik ragam menunjukkan bahwa karbohidrat pada cookies berpengaruh nyata terhadap penambahan tepung labu kuning, berdasarkan hasil uji lanjut Duncan ( $\mathrm{p}<$
\end{abstract}


0,00). Hasil uji analisa protein menunjukkan bahwa kandungan protein tertinggi pada perlakuan $\mathrm{P} 4$ sebesar $8,44 \%$ pengulangan 1 dan $7,46 \%$ pada pengulangan 2 , sedangkan terendah pada perlakuan PO sebesar $7,17 \%$ pengulangan 1 dan $7,44 \%$ pada pengulangan 2 , analisa sidik ragam menunjukkan bahwa protein pada kue cookies berpengaruh sangat nyata terhadap penambahan tepung labu kuning, berdasarkan hasil uji lanjut Duncan $(\mathrm{p}<0,00)$. Disimpulkan bahwa penambahan tepung labu kuning berpengaruh nyata terhadap kadar karbohidrat dan protein pada cookies.

Kata kunci: cookies; karbohidrat; labu kuning; protein

\section{PENDAHULUAN}

Labu kuning adalah komoditas yang mudah rusak, maka perlu adanya penanganan lepas panen termasuk pengawetan dan pengolahan yang lebih stabil. Labu kuning termasuk jenis sayuran yang dapat tumbuh pada dataran rendah sampai dataran tinggi antara 0 sampai 1200 di atas permukaan laut (Apandi, 2013). Labu kuning memiliki banyak kelebihan dibandingkan dengan komoditas yang lain, antara mempunyai aroma dan citarasa yang khas, serta sumber vitamin A karena kaya akan karoten selain mengandung zat gizi lainnya seperti karbohidrat, mineral, protein, dan vitamin. Selain itu, buah labu kuning mengandung inulin dan serat pangan yang dibutuhkan untuk pemeliharaan kesehatan, khususnya saluran pencernaan (Purwanto dkk, 2013).

Labu kuning merupakan salah suatu bahan pangan yang produksinya melimpah di Indonesia dan mengandung beta karoten cukup tinggi yaitu sebesar $1569 \mu \mathrm{g} / 100$ gr. Selama ini labu kuning hanya dimanfaatkan untuk dikonsumsi sebagai sayuran (Miyasto, 2013). Namun pada saat ini pemanfaatan labu kuning belum maksimal, menurut Data Badan Pusat Statistik menunjukkan hasil rata-rata produksi labu kuning seluruh Indonesia berkisar antara 20-21 ton per hektar, sedangkan konsumsi labu kuning di Indonesia masih sangat rendah, yaitu kurang dari $5 \mathrm{~kg}$ per kapita per tahun. Kabupaten Gorontalo merupakan salah satu produsen labu kuning yang cukup potensial, karena kondisi tanah dan wilayah yang sangat mendukung. Sebagaimana yang terjadi secara umum problem labu kuning di Kabupaten Gorontalo menyangkut fluktuasi harga yang selalu menjadi kekhawatian petani. Strategi mengurangi resiko dan ketidakpastian dalam pengembangan labu kuning yang dimaksudkan untuk lebih meningkatkan daya simpan dan nilai tambah (BPS Gorontalo, 2012). Mengingat kandungan gizinya yang cukup lengkap, harganya yang relatif murah, dan pemanfaatannya yang masih minim, maka labu kuning ini merupakan sumber gizi yang sangat potensial untuk dikembangkan sebagai salah satu alternatif dalam pengembangan produk labu kuning (Miyasto, 2013).

Labu kuning merupakan jenis tanaman sayuran, yang memiliki kandungan gizi yang cukup lengkap yaitu karbohidrat, protein, beberapa mineral seperti kalsium, fosfor, besi, serta vitamin yaitu vitamin B dan C dan serat. Labu kuning merupakan sumber vitamin A dan kandungan ß-karoten yang tinggi 180,00 SI (sekitar 1.000-1.300 IU/100g bahan) (Hendrasty, 2003). Labu kuning atau waluh merupakan bahan pangan yang kaya vitamin A dan $\mathrm{C}$, mineral, serta karbohidrat. Labu kuning mengandung antiokisidan sebagai penangkal berbagai jenis kanker. Dalam membuat suatu hidangan tertentu, seperti labu kuning biasa dijadikan cookies. Kue kering atau cookies adalah jenis makanan ringan yang mudah didapat dan digemari oleh berbagai kalangan, baik tua maupun muda (Lestario, 2012). Berdasarkan uraian tersebut maka perlu dilakukan penelitian untuk mengetahui nilai kandungan gizi labu kuning dalam pembuatan cookies dari labu kuning dalam meningkatan nilai tambah produk. 


\section{METODE}

Penelitian dilaksanakan pada bulan Juni sampai Agustus 2019, di Laboratorium Terpadu Fakultas Kesehatan Masyarakat Universitas Gorontalo yaitu mulai proses pengolahan hingga pembuatan cookies, sedangkan uji analisis karbohidrat, protein, vitamin C dilakukan di Laboratorium Pengolahan Analisa dan Pengawasan Mutu Pangan Program Studi Teknologi Pangan, Fakultas Pertanian, Universitas Hasanunddin.

Bahan yang digunakan dalam penelitian adalah labu kuning yang diperoleh dari Kabupaten Gorontalo. Bahan lainnya dalam pembuatan cookies adalah gula, margarin, susu skim, bubuk cokelat dan garam, air bersih. Sementara untuk analisis kadar karbohidrat, protein dan vitamin $\mathrm{C}$ menggunakan larutan $\mathrm{NaOH}$, aquadest, metanol, alkohol 94. Alat yang digunakan dalam penelitian ini untuk pembuatan tepung dan cookies labu kuning adalah oven, blender, timbangan analitik, ayakan 60 mesh, wadah plastik, pisau, mixer, sendok, pencetakan adonan, kertas label. Sementara alat untuk analisa karbohidrat, protein dan vitamin $\mathrm{C}$ digunakan oven, pengering dengan kabinet otomatis, soxhlet, thermometer, cawan porselen, alat sentrifugasi, penjepit, timbangan analitik, erlenmeyer, gelas kimia, batang pengaduk, pipet mikro, kertas saring, kertas label.

Prosedur kerja pembuatan cookies labu kuning meliputi labu kuning yang telah dikupas, dibuang bagian kulit, jaring-jaring dan bijinya serta dicuci bersih, kemudian diiris dengan ketebalan 1-2 mm, dikeringkan dengan pengering kabinet otomatis dengan suhu $50^{\circ} \mathrm{C}$ selama 12 jam. Labu kuning yang sudah kering kemudian dihancurkan dengan blender hingga halus, kemudian diayak dengan ayakan 60 mesh, sehingga didapatkan tepung labu kuning. Kemudian dilakukan pencampuran bahan mula-mula gula, margarin, susu skim dan garam, bubuk cokelat dicampurkan tepung labu kuning dengan variasi yaitu dengan penambahan tepung labu kuning pada perlakuan P0 (60 gr), P1 (100 gr), P2 (150 gr), P3 (150 gr), P4 (250 gr, dilanjutkan pengocokan sedemikian rupa sehingga semua bahan tercampur hingga rata atau homogen. Setelah adonan jadi dilakukan dengan pencetakan. Tahap berikutnya adalah pembakaran yang dilakuan dengan oven pada $100^{\circ} \mathrm{C}$ selamat 30 menit. Selanjutnya dinginkan, setelah dingin kemudian kemasan. Selanjutnya dilakukan pengujian (Trisnawati $\mathrm{dkk}, 2014)$.

Analisa data pada penelitian ini yaitu analisa karbohidrat, protein dan vitamin $\mathrm{C}$. Metode penelitian yang digunakan adalah true experimental design dan teknik analisa data menggunakan parameter pengamatan pada penelitian ini yaitu kadar karbohidrat, protein dan vitamin $\mathrm{C}$ menggunakan rancangan percobaan yang disusun dalam rancangan acak lengkap (RAL) dengan variasi penambahan tepung labu kuning pada perlakuan P0 (60 gr), P1 (100 gr), P2 (150 gr), P3 (200 gr), P4 (250 gr) dengan perlakuan yang terdiri dari dua kali ulangan menggunakan bantuan program aplikasi SPSS 16, jika hasilnya menunjukkan signifikan maka akan dilanjutkan dengan uji lanjut (Agusman, 2013).

\section{HASIL DAN PEMBAHASAN}

\section{Analisa Kandungan Tepung Labu Kuning}

Pengeolahan labu kuning menjadi tepung labu merupakan salah satu cara yang mungkin dapat dilakukan untuk meningkatkan daya simpan produk labu kuning agar tidak mengalami kerusakan. Pengolahan buah labu kuning menjadi tepung mempunyai beberapa kelebihan dibanding buah segarnya (Basito, 2013). Labu kuning merupakan buah yang masih jarang dimanfaatkan oleh industri pangan. Komponen protein yang semakin sempurna saat diikuti oleh proses penyangraian yang semakin baik sehingga pembentukan citarasa dan aroma 
semakin baik akibatnya rasa dan aroma yang dihasilkan semakin baik. Suhu yang semakin tinggi dapat mengakibatkan pengembangan granula pati yang lebih membengkak lagi, terjadi pelarutan fraksi amilosa rendah dan selanjutnya terjadi pemecahan granula pati dan kemudian tersebar merata (Estiasih dan Ahmadi, 2014).

Pengolahan tepung labu kuning dalam suatu produk berpengaruh terhadap kadar air dan penyerapan air sehingga dapat memperbaiki tekstur. Hal ini disebabkan karena adanya kandungan protein yang mempunyai sifat fungsional yang dapat mengikat dan menahan air (Trisnawati dkk, 2014). Makin tinggi persentase penggunaan tepung labu kuning akan semakin renyah karena adanya pengaruh lemak. Faktor warna merupakan parameter awal yang secara subjektif dan visual harus dipertimbangkan karena dapat menyebabkan penerimaan atau penolakan produk (Thenir dkk, 2017). Perubahan warna akibat reaksi maillard antara gula pereduksi dengan asam amino dan hasil akhirnya adalah melanoidin (Suratno dkk, 2014). Hal ini disebabkan karena warna labu kuning memiliki warna gelap pada saat di oven untuk dipanaskan.

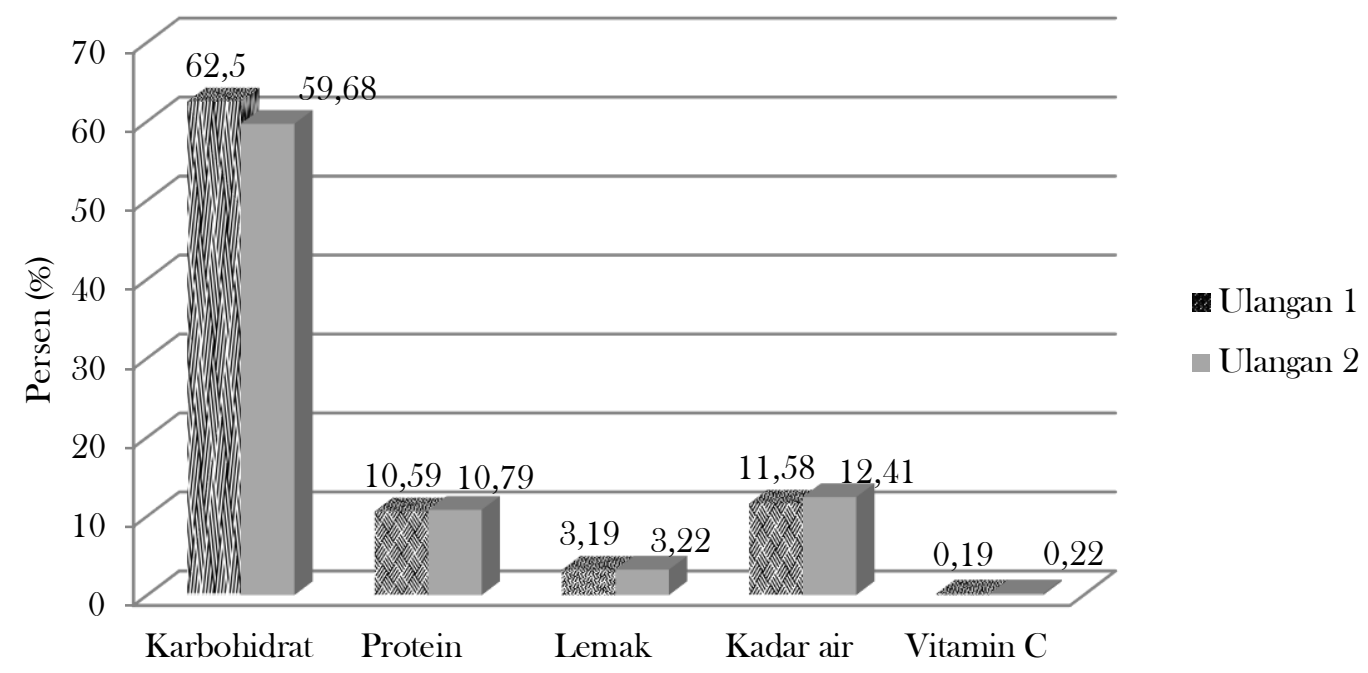

Gambar 1. Hasil Analisa Uji Kandungan Tepung Labu Kuning

Berdasarkan hasil penelitian ini menunjukan bahwa kandungan tepung labu kuning yaitu kandungan karbohidrat sebanyak $62,50 \%$ pada ulangan 1 sedangan ulangan 2 sebanyak $59,68 \%$, sedangkan kandungan protein pada tepung labu kuning pada ulangan 1 sebanyak 10,59\%, ulangan 2 sebanyak $10,79 \%$. Kandungan lemak pada tepung labu kuning pada ulangan 1 sebanyak $3,19 \%$, ulangan 2 sebanyak 3,22\%. Kandungan kadar air pada tepung labu kuning pada ulangan 1 sebanyak $11,58 \%$, ulangan 2 sebanyak $12,41 \%$. Sedangan kandungan vitamin $\mathrm{C}$ pada tepung labu kuning pada ulangan 1 sebanyak 0,19\%, ulangan 2 sebanyak 0,22\%. Hal ini menunjukkan bahwa pengaruh pengolahan tepung labu kuning dipengaruhi oleh kadar air dan penyerapan air sehingga dapat memperbaiki tekstur. Hal ini disebabkan karena adanya kandungan protein yang mempunyai sifat fungsional yang dapat mengikat dan menahan air. Salah satu diversifikasi produk olahan labu kuning dapat dikembangkan sebagai pangan fungsional yang berkaitan dengan konsep indeks glikemik (IG), pangan dengan indeks glikemiks rendah akan mebantu meningkatkan kesehatan. Potensi labu kuning sebagai pangan fungsional terkait dengan zat gizi yang dikandungnya, setiap $100 \mathrm{~g}$ labu kuning mengadung energi $29 \mathrm{kkal}$, protein 1,1 gr, lemak 0,3 gr, karbohidrat 6,6 gr dan vitamin A 180 SI. Kandungan Karbohidrat tepung labu kuning (77,65\%). Pengembangan tekstur bahan merupakan segi penting dari mutu makanan, 
kadang-kadang lebih penting dari pada bau rasa dan warna. Ciri yang paling sering diacu adalah kekerasan, kekohesifan, dan kandungan air (Miyasto, 2013). Tekstur termasuk dalam salah satu faktor yang mempengaruhi penerimaan konsumen terhadap produk pangan (Thenir dkk, 2017).

\section{Kandungan Karbohidrat Cookies Labu Kuning}

Kerusakan karbohidrat terjadi ketika polimer terhidrolisis dan pecah. Karbohidrat yang rusak akan mengakibatkan penurunan kadar karborhidrat. Perubahan sifat air yang terjadi akan dipengaruhi oleh jenis dan jumlah partikel yang terdispersi dalam air. Air dalam bahan pangan berperan sebagai pelarut dari beberapa komponen di samping ikut sebagai bahan pereaksi sedangkan bentuk air dapat ditemukan sebagai air bebas dan air terikat (Martunis, 2015). Air bebas dapat dengan mudah hilang apabila terjadi penguapan yang dapat terikat secara fisik, yaitu air terikat secara kimia. Hasil pengamatan pengujian karbohidrat produk kue cookeis dari labu kuning ditunjukkan pada Gambar 2.

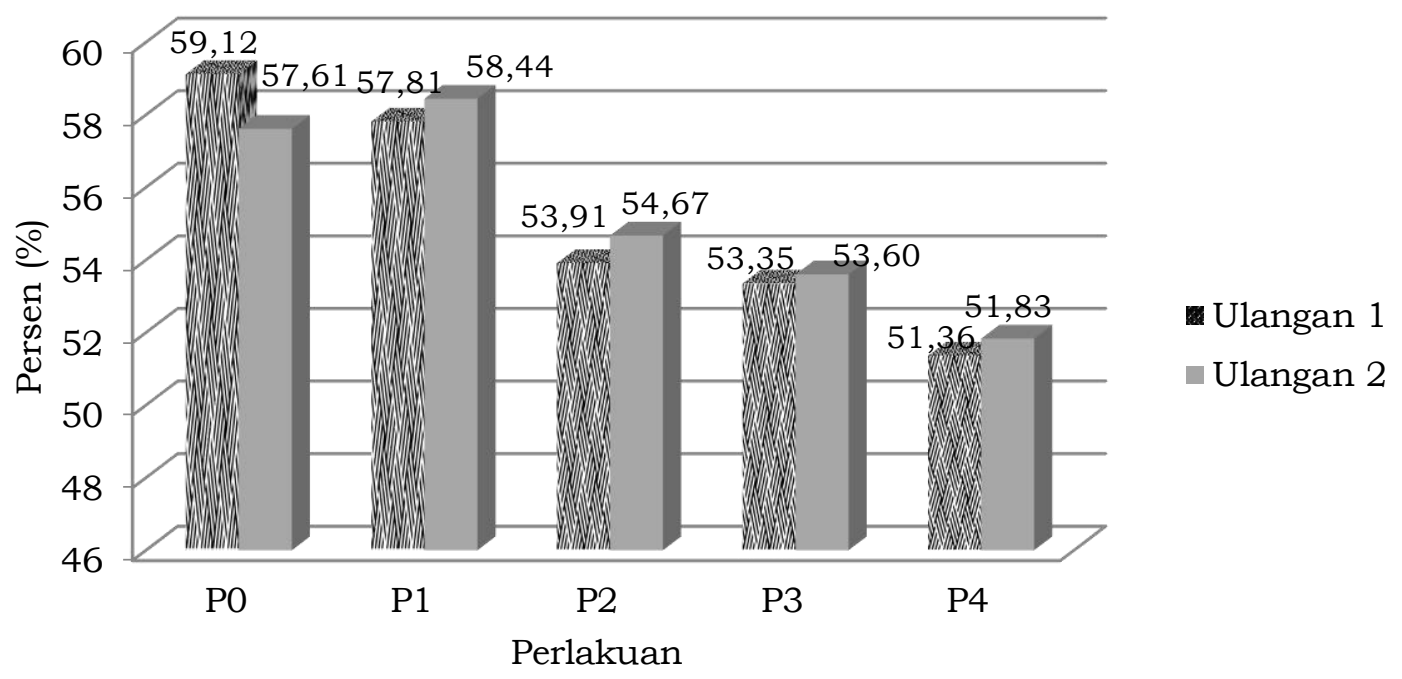

Gambar 2. Hasil Analisa Uji Karbohidrat Cookies Labu Kuning

Berdasarkan hasil uji analisa karbohidrat pada cookies menunjukkan bahwa kandungan karobohdat tertinggi pada perlakuan PO sebesar 59,12\% dengan penambahan tepung labu kuning sebanyak 60 gr sedangkan terendah pada perlakuan P4 sebesar 51,36\% dengan penambahan tepung labu kuning sebanyak 250 gr. Kandungan karbohidrat pada perlakuan P1 ulangan 1 sebesar $57,81 \%$, sedangkan pada ulangan 2 sebesar 58,44\% dengan penambahan tepung labu kuning sebanyak 100 gr. Sedangkan kandungan karbohidrat pada perlakuan P2 ulangan 1 sebesar 53,91\% dan ulangan 2 sebesar 54,64\% dengan penambahan tepung labu kuning sebanyak 150 gr. Kandungan karbohidrat pada perlakuan P3 ulangan 1 sebesar 53,35\% dan ulangan 2 sebesar 53,60\% dengan penambahan tepung labu kuning sebanyak 200 gr.

Hasil analisa sidik ragam analisa karbohidrat pada cookies menunjukkan berpengaruh sangat nyata, hasil uji lanjut Duncan menunjukan pada perlakuan P0 dan P1 berpengaruh sangat nyata terhadap perlakuan P2 pada cookies dari tepung labu kunig, hal ini ditunjukkan dengan nilai sig $(\mathrm{p}<0,00)$. Hal ini dapat disebabkan reaksi maillard yang terjadi selama proses pengolahan, yang menyebabkan adonan berubah menjadi renyah pada produk melalui pemanggangan. Proses pengolahan dapat bersifat menguntungkan terhadap karbohidrat yang terkandung dalam bahan pangan yaitu perubahan kadar 
kandungan karbohidrat dan peningkatan daya cerna. Proses pemanasan bahan pangan dapat meningkatkan ketersediaan karbohidrat (Purwanto dkk, 2013).

Karbohidrat adalah senyawa yang terbentuk dari molekul karbon, hidrogen dan oksigen. Sebagai salah satu jenis zat gizi yang fungsi utama karbohidrat adalah penghasil energi di dalam tubuh (Murdianto dkk, 2014). Tiap 1 gram karbohidrat yang dikonsumsi akan menghasilkan energi sebesar 4 kkal dan energi hasil proses oksidasi (pembakaran) karbohidrat kemudian akan digunakan oleh tubuh untuk menjalankan berbagai fungsinya seperti bernafas, kontraksi jantung dan otot serta untuk menjalankan berbagai aktivitas fisik seperti berolahraga atau bekerja. Karbohidrat merupakan sumber energi bagi aktivitas kehidupan manusia disamping protein dan lemak (Faridah dkk, 2008). Di Indonesia kurang lebih $80-90 \%$ kebutuhan energi berasal dari karbohidrat, karena makanan pokok orang Indonesia sebagian besar mengandung karbohidrat. Proses pengolahan dapat bersifat menguntungkan terhadap karbohidrat yang terkandung dalam bahan pangan yaitu perubahan kadar kandungan karbohidrat dan peningkatan daya cerna (Faridah dkk, 2008).

\section{Kandungan Vitamin C Cookies Labu Kuning}

Vitamin $\mathrm{C}$ telah dikenal sebagai antioksidan potensial yang mampu menangkap radikal bebas dalam tubuh serta mencegah hiperpigmentasi. Radikal bebas dalam tubuh sendiri dapat meningkat pada kondisi tubuh yang telah tua maupun karena paparan sinar matahari yang berlebihan. Hasil pengamatan pengujian Vitamin C produk cookies ditunjukkan pada Gambar 3.

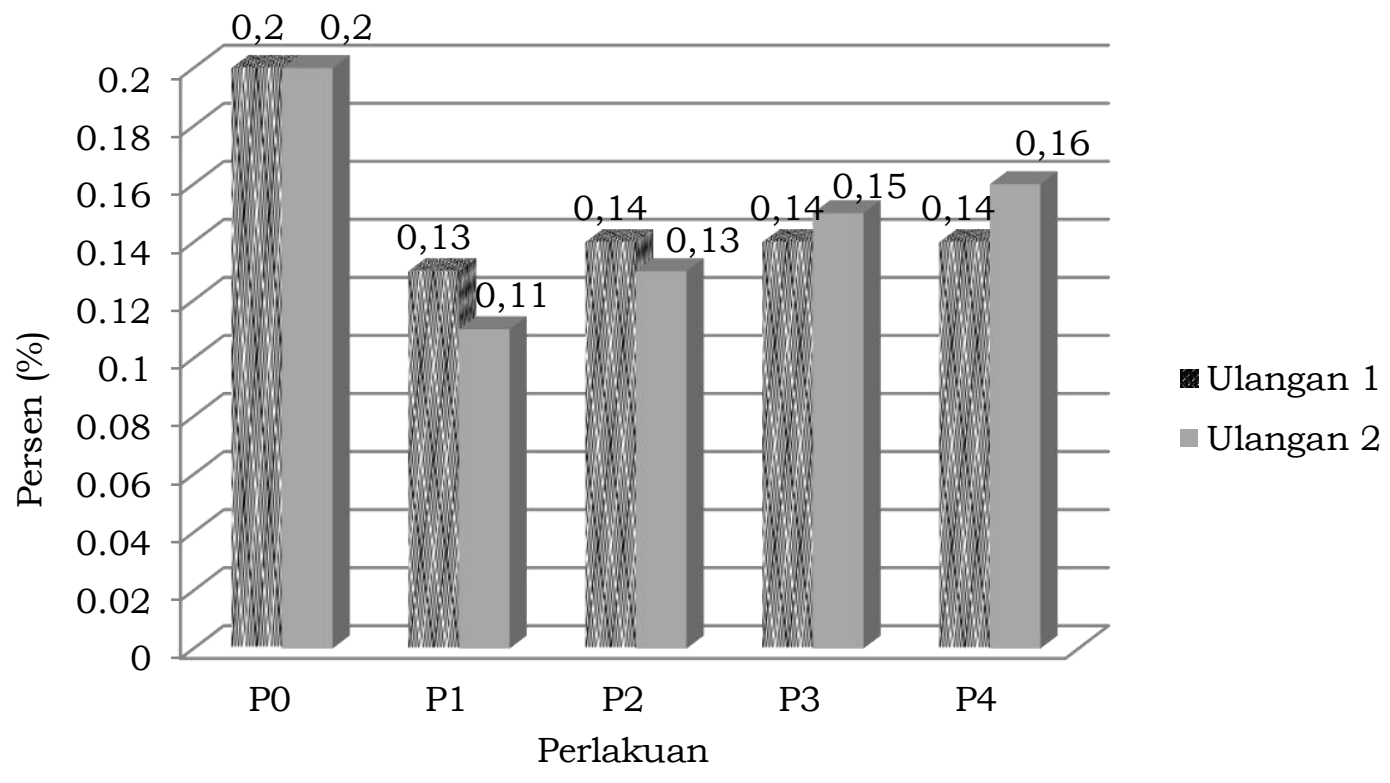

Gambar 3. Hasil Analisa Uji Vitamin C pada Cookies Labu Kuning

Berdasarkan hasil uji analisa Vitamin $\mathrm{C}$ pada cookies menunjukkan bahwa kandungan Vitamin $\mathrm{C}$ tertinggi pada perlakuan PO sebesar 0,20\% dengan penambahan tepung labu kuning sebanyak 60 gr sedangkan terendah pada perlakuan P1 sebesar $0,11 \%$ dengan penambahan tepung labu kuning sebanyak 100 gr. Kandungan vitamin $\mathrm{C}$ pada perlakuan P4 ulangan 1 sebesar $0,14 \%$ ulangan 2 sebesar $0,16 \%$ dengan penambahan tepung labu kuning sebanyak 250 gr. Sedangkan kandungan Vitamin C pada perlakuan P3 ulangan 1 sebesar $0,14 \%$ ulangan 2 sebesar $0,15 \%$ dengan penambahan tepung labu kuning sebanyak 200 gr. Kandungan Vitamin C pada perlakuan P2 ulangan 1 sebesar $0,14 \%$ ulangan 2 sebesar $0,13 \%$ dengan penambahan tepung labu kuning sebanyak 150 gr. Hilangnya kandungan vitamin $\mathrm{C}$ diduga karena adanya 
perubahan struktur jaringan cookies, dimana semakin tinggi larutan gula yang ditambahkan maka mengakibatkan lebih banyak molekul-molekul air bergerak keluar dari bahan dan air dapat melarutkan vitamin $\mathrm{C}$, sehingga pada akhirnya vitamin C bahan berkurang (Suratno dkk, 2014; Apandi, 2013).

Hasil analisa sidik ragam menunjukkan bahwa vitamin $\mathrm{C}$ pada cookies berpengaruh sangat nyata terhadap penambahan tepung labu kuning, berdasarkan hasil uji lanjut Duncan yang menunjukkan pada P4, P1, P3, dan P2 yaitu sangat berpangaruh nyata terhadap perlakuan PO pada cookies dari tepung labu kuning, hal ini ditunjukkan dengan nilai sig $(\mathrm{p}<0,00)$. Hal ini dapat disebabkan semakin tinggi konsentrasi gula yang ditambahkan dapat menurunkan kandungan vitamin $\mathrm{C}$ pada labu kuning. Vitamin $\mathrm{C}$ tergolong vitamin yang larut dalam air yang dapat berbentuk sebagai asam L-askorbat dan asam L-dehidro askorbat, keduanya mempunyai keaktifan sebagai vitamin $\mathrm{C}$. Asam askorbat sangat mudah teroksidasi secara reversible menjadi asam Ldehidro askorbat. Asam dehidro askorbat secara kimia sangat labil dan dapat mengalami perubahan lebih lanjut menjadi asam L-diketoglukonat yang tidak memiliki keaktifan vitamin C (Sukarsih, 2011).

Kandungan vitamin $\mathrm{C}$ dalam bahan pangan atau makanan sangat diperlukan oleh tubuh, karena vitamin berfungsi sebagai zat pengatur dan pelindung tubuh dari gangguan penyakit serta dapat melancarkan metabolisme (Estiasih dan Ahmadi, 2011). Rata-rata arbsorbsi vitamin C adalah 90\% untuk konsumsi diantara $20-120 \mathrm{mg} /$ hari. Konsumsi tinggi sampai 12 gram hanya diarbsorbsi sebanyak 16\% (Sukarsih, 2011). Secara umum reaksi oksidasi vitamin C ada dua macam yaitu proses oksidasi spontan dan proses oksidasi tidak spontan. Proses oksidasi spontan adalah proses oksidasi yang terjadi tanpa menggunakan enzim atau katalisator (Purwanto dkk, 2013).

\section{Kandungan Protein Cookies Labu Kuning}

Protein berperan dalam proses pembentukan enzim dan hormon yang dapat mengatur proses metabolisme dalam tubuh, dan sebagai antibodi. Protein berfungsi dalam mekanisme pertahanan tubuh melawan berbagai macam penyakit dan infeksi. Protein merupakan salah satu kelompok bahan makronutrien yang lebih berperan penting dalam pembentukan biomolekul daripada sumber energy (Faridah dkk, 2008). Pada prinsipnya suatu protein yang dapat menyediakan asam amino esensial dalam suatu perbandingan yang menyamai kebutuhan manusia, mempunyai mutu yang tinggi. Sebaliknya protein yang kekurangan satu atau lebih asam amino esensial mempunyai mutu yang rendah (Andarwulan dkk, 2011). Pengaruh penambahan tepung labu kuning pada perlakuan P0 (60 gr), P1 (100 gr), P2 (150 gr), P3 (200 gr), P4 (250 gr) ditunjukkan pada Gambar 4.

Berdasarkan hasil uji analisa protein pada cookies menunjukkan bahwa kandungan protein tertinggi pada perlakuan P4 sebesar 8,44\% dengan penambahan tepung labu kuning sebanyak 250 gr sedangkan terendah pada perlakuan PO sebesar $7,17 \%$ dengan penambahan tepung labu kuning sebanyak 60 gr. Kandungan protein pada perlakuan P1 ulangan 1 sebesar 7,84\% ulangan 2 sebesar $7,56 \%$ dengan penambahan tepung labu kuning sebanyak 100 gr. Sedangkan kandungan protein pada perlakuan P2 ulangan 1 sebesar $7,26 \%$ ulangan 2 sebesar 7,39\% dengan penambahan tepung labu kuning sebanyak 150 gr. Kandungan protein pada perlakuan P3 ulangan 1 sebesar $7,65 \%$ ulangan 2 sebesar 7,64\% dengan penambahan tepung labu kuning sebanyak 200 gr. Proses kerusakan atau penurunan protein disebabkan proses oksidasi. Secara umum reaksi oksidasi vitamin $C$ ada dua macam yaitu proses oksidasi spontan dan proses oksidasi tidak spontan. Proses oksidasi spontan 
adalah yang terjadi tanpa menggunakan enzim atau katalisator. Sedangkan proses oksidasi tidak spontan yaitu reaksi yang terjadi dengan adanya penambahan enzim atau katalisator, misal enzim glutation (Prabasini dkk, 2013).

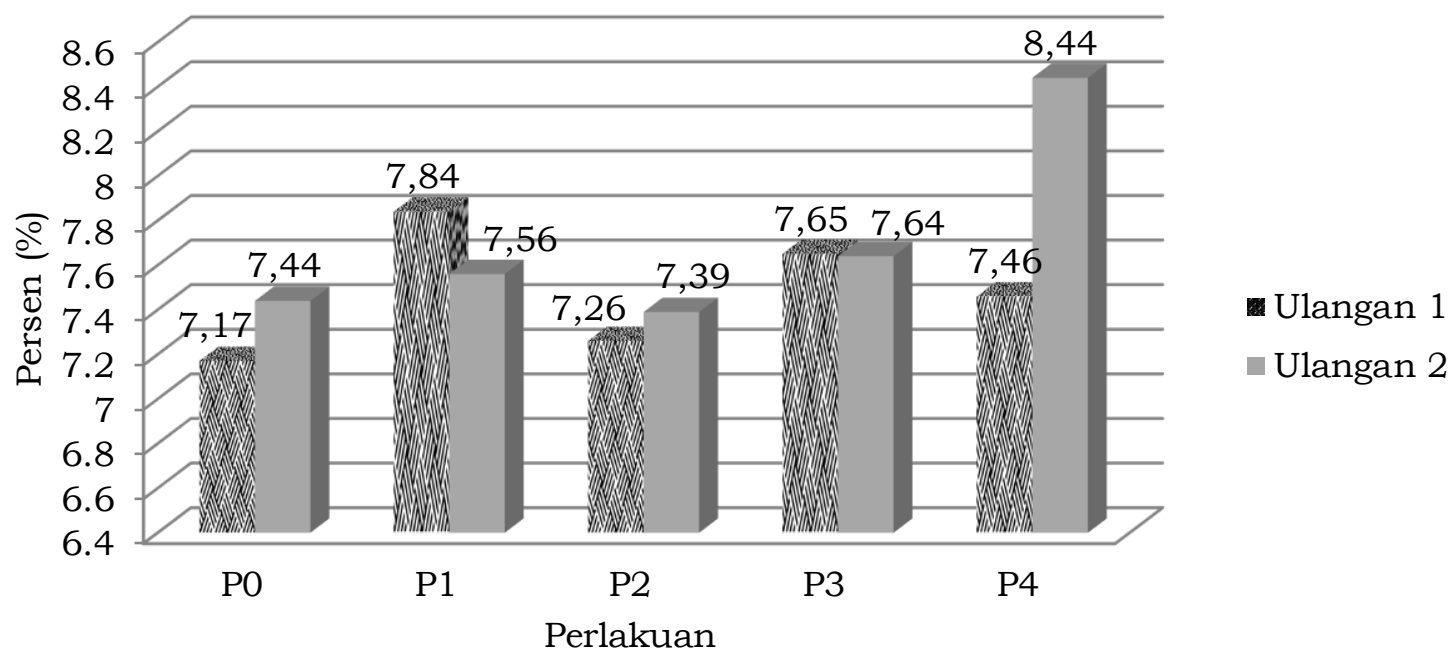

Gambar 4. Hasil Analisa Uji Protein Cookies Labu Kuning

Hasil analisa sidik ragam menunjukkan bahwa protein pada cookies berpengaruh sangat nyata terhadap penambahan tepung labu kuning, berdasarkan hasil uji lanjut Duncan yang menunjukkan pada P4, P3, P1, dan P0 yaitu sangat berpangaruh nyata terhadap perlakuan P2 pada cookies labu kuning, hal ini ditunjukkan dengan nilai sig $(p<0,00)$. Semakin tinggi konsentrasi gula yang ditambahkan dapat menurunkan kandungan protein pada labu kuning. Kekerasan mengacu kepada panjang atom (panjang rantai hidrokarbon) dan derajat kejenuhan asam lemak (ikatan rangkap hidrokarbon) sebagai komponen penyusunnya. Semakin panjang rantai hidrokarbon utama pada suatu asam lemak, maka sifat lemak akan semakin keras. Dimana daya reaksi untuk mengikat ditentukan oleh posisi ikatan rangkapnya (Purwanto, 2013). Penelitian terdahulu menunjukkan semakin tinggi penambahan labu kuning dan ikan gabus akan meningkatkan kadar protein. Hal tersebut disebabkan oleh tingginya kadar protein dalam ikan gabus dan labu kuning (Sukarsih, 2014).

Protein merupakan sumber asam-asam amino yang sangat dibutuhkan oleh tubuh manusia. Semakin tinggi penambahan labu kuning semakin tinggi protein cookies. Komponen protein yang semakin baik saat diikuti oleh proses penyangraian akibatnya rasa dan aroma yang dihasilkan semakin baik (Rahmi dkk, 2011). Suhu yang semakin tinggi dapat mengakibatkan pengembangan granula pati yang lebih membengkak lagi, terjadi pelarutan fraksi amilosa rendah dan selanjutnya terjadi pemecahan granula pati dan kemudian tersebar merata. Perubahan sifat air yang terjadi akan dipengaruhi oleh jenis dan jumlah partikel yang terdispersi dalam air (Faridah, 2008). Bentuk air dapat ditemukan sebagai air bebas dan air terikat. Air bebas dapat dengan mudah hilang apabila terjadi penguapan yang dapat terikat secara fisik, yaitu air terikat secara kimia, antara lain air kristal dan air yang terikat dalam sistem disperse. Tepung labu kuning diolah melalui proses pengupasan, pencucian, penjemuran hingga kering, penghalusan (Estiasih dan Ahmadi, 2011). Adanya pengaruh panas selama pengolahan dan lamanya waktu pengeringan dapat merusak karoten pada tepung labu kuning (Purwanto,2013). Makin lama waktu yang dibutuhkan dalam proses pengeringan, makin banyak jumlah oksigen yang terlibat dalam 
proses pengeringan, sehingga jumlah karoten yang rusak karena oksidasi makin besar (Martunis, 2015).

\section{PENUTUP}

Berdasarkan hasil penelitian disimpulkan bahwa hasil uji analisa karbohidrat pada cookies menunjukkan kandungan karbohidat tertinggi pada perlakuan PO sebesar 59,12\% dengan penambahan tepung labu kuning sebanyak 60 gr sedangkan terendah pada perlakuan P4 sebesar $51,36 \%$ dengan penambahan tepung labu kuning sebanyak 250 gr. Hasil uji lanjut Duncan menunjukan pada perlakuan P0 dan P1 berpengaruh sangat nyata terhadap perlakuan P2 pada cookies labu kunig (nilai sig $\mathrm{p}<0,00$ ). Hasil uji analisa protein cookies menunjukkan kandungan protein tertinggi pada perlakuan P4 sebesar 8,44\% dengan penambahan tepung labu kuning sebanyak 250 gr sedangkan terendah pada perlakuan PO sebesar $7,17 \%$ dengan penambahan tepung labu kuning sebanyak 60 gr dengan hasil uji lanjut Duncan yang menunjukkan pada P4, P3, P1, dan PO yaitu sangat berpangaruh nyata terhadap perlakuan P2 cookies tepung labu kuning (nilai sig $\mathrm{p}<0,00$ ).

\section{UCAPAN TERIMA KASIH}

Terimakasih kepada Direktorat Jenderal Penguatan dan Pengembangan Ristekdikti atas bantuan yang diberikan kepada tim peneliti, hingga kegiatan penelitian ini dapat berjalan dengan baik. Terimakasih kepada pihak Lembaga Penelitian dan Pengabdian Masyarakat (LP3M) Universitas Gorontalo atas bantuanya selama pelaksanaan penelitian.

\section{DAFTAR PUSTAKA}

Agusman. 2013. Pengujian Bahan Pangan. Universitas Muhamadiyah Semarang. Semarang.

Andarwulan N, Feri K dan Dian I. 2011. Analisis Pangan. Dian Rakyat. Jakarta. Apandi. 2013. Teknologi Buah dan Sayur. Penerbit Alumni. Bandung.

Badan Pusat Statistik Provinsi Gorontalo. 2012. Gorontalo Dalam Angka. Gorontalo: Badan Pusat Statistik Provinsi Gorontalo.

Basito, Yanuwarda, Dimas RA. 2013. Kajian Karakteristik Fisikokimia Tepung Labu Kuning (Cucurbita moschata) Termodifikasi dengan Variasi Lama Perendaman dan Konsentrasi Asam Laktat. Jurnal Teknosains Pangan. 2(2): 75-83.

Estiasih T dan Ahmadi. 2011. Teknologi Pengolahan Pangan. Bumi Aksara. Jakarta.

Faridah A, Kasmita SP, Yulastri A. Yusuf L. 2008. Patiseri Jilid 3. Jakarta. Direktorat Pembinaan Sekolah Menengah Kejuruan.

Hendrasty. 2003. Tepung Labu Kuning : Pembuatan dan Pemanfaatannya. Yogyakarta. Karnisium.

Lestario LN, Maria S, Yohanes M. 2012. Pemanfaatan Tepung Labu Kuning (Cucurbita moschata duch) sebagai Bahan Fortifikasi Mie Basah. Prosiding Seminar Nasional Sains dan Pendidikan Sains VII. Salatiga: Universitas Kristen Satya Wacana.

Martunis. 2015. Pengaruh Suhu dan Lama Pengeringan terhadap Kualitas dan Kuantitas Pati Kentan Varietas Granola. Jurnal Teknologi Industri dan Pertanian Indonesia. 4(3): 26-30.

Miyasto. 2013. Meningkatkan Produktivitas Pertanian Guna Mewujudkan Ketahanan Pangan dalam Rangka Ketahanan Nasional, Pengkajian Bidang Ekonomi. Edisi 15. 
Murdianto W, Syahrumsyah H, Yanti S. 2014. Formulasi Labu kuning (Cucurbita Moschata) dan Kelapa Parut terhadap Karakteristik Kimia dan Sensoris pada Pembuatan Cookies. Prosiding Seminar Nasional Kimia. Samarinda: Universitas Mulawarman.

Prabasini H, Ishartani D, Rahadian D. 2013. Kajian Sifat Kimia dan Fisik Tepung Labu Kuning (Cucurbita moschata) dengan Perlakuan Blanching dan Perendaman Natrium Metabisulfit (Na2S2O5). Jurnal Teknosains Pangan. 2(2): 93-102.

Purwanto CC, Ishartani D, Muhammad DRA. 2013. Kajian Fisika Kimia Tepung Labu Kuning (Cucurbita Maxima) dengan Perlakuan Blaching dan Perendaman Natrium Metabisulfit. Jurnal Teknologi Pangan. 2(2): 121130.

Rahmi SL, Indriyani, Suharini. 2011. Penggunaan Buah Labu Kuning sebagai Sumber Antioksidan dan Pewarna Alami pada Produk Mie Basah. Jurnal Penelitian Universitas Jambi Seri Sains. 13(2): 29-36.

Sukarsih. 2011. Pembuatan Dodol Labu Kuning. Jurusan Teknik Kerumah Tanggaan UNM. 4(1): 98-99.

Suratno YD, Palupi NS, Astawan M. 2014. Pola Konsumsi Pangan Fungsional dan Formulasi Minuman Fungsional Instan Berbasis Antioksidan. Jurnal Mutu Pangan. 1(1): 56-64.

Thenir R, Ansharullah, Djukrana W. 2017. Pengaruh Substitusi Tepung Labu Kuning (Cucurbita moschata) terhadap Penilaian Organoleptik dan Analisis Proksimat Kue Bolu Mangkok. Jurnal Sains dan Teknologi Pangan. 2(1).

Trisnawati W, Suter K, Suastika K, Putra NK. 2014. Pengaruh Metode Pengeringan terhadap Kandungan Antioksidan, Serat Pangan dan Komposisi Gizi Tepung Labu Kuning. Jurnal Aplikasi Teknologi Pangan.3(4): 135-140. 